\title{
PENGARUH EARNING PER SHARE, DEBT TO EQUITY RATIO, PRICE EARNING RATIO, RETURN ON EQUITY TERHADAP HARGA SAHAM PERUSAHAAN MAKANAN DAN MINUMAN DI BEI PERIODE 2015-2017
}

\author{
Indrian Trifena Suriadi \\ Program Studi Magister Manajemen Universitas Tarumanagara \\ trifena_indri@yahoo.com \\ Indra Widjaja \\ Program Studi Magister Manajemen Universitas
}

\begin{abstract}
This study aims to determine the effect of financial performance on stock returns in food and beverage companies listed on the Indonesia Stock Exchange in 2015 to 2017 simultaneously or partially. The variables used in this study are Earning Per Share (EPS), Debt To Equity Ratio (DER), Price Earning Ratio (PER), Return On Equity (ROE) as independent variables and stock return as the dependent variable. The data used are financial statements from food and beverage companies published through the website ww.idx.co.id. The results of the study show that the independent variables EPS, DER, PER, ROE do not significantly influence the dependent variable (stock return) simultaneously. While the results of the study are partial, it shows that only EPS and ROE variables have a significant effect on stock returns. Thus it can be concluded that all the independent variables studied cannot be used simultaneously to determine the amount of stock returns. The data analysis method used in this study is a quantitative method by testing classical assumptions, as well as statistical analysis, namely multiple linear regression analysis. The sampling method used was purposive sampling.
\end{abstract}

Abstrak : Penelitian ini bertujuan untuk mengetahui pengaruh kinerja keuangan terhadap return saham pada perusahaan makanan dan minuman yang terdaftar di Bursa Efek Indonesia pada tahun 2015 sampai dengan 2017 secara serempak maupun parsial. Variabel yang digunakan dalam penelitian ini adalah Earning Per Share (EPS), Debt To Equity Ratio (DER), Price Earning Ratio (PER), Return On Equity (ROE) sebagai variabel independen dan Return saham sebagai variabel dependen. Data yang digunakan adalah laporan keuangan dari perusahaan makanan dan minuman yang dipublikasikan melalui website ww.idx.co.id Hasil penelitian menunjukkan bahwa variabel independen EPS, DER, PER, ROE tidak berpengaruh secara signifikan terhadap variabel dependen (Return saham) secara serempak. Sementara hasil penelitian secara parsial, menunjukkan bahwa hanya variabel EPS dan ROE yang berpengaruh signifikan terhadap Return saham. Dengan demikian dapat diambil kesimpulan bahwa seluruh variabel independen yang diteliti tidak dapat digunakan secara serempak untuk menentukan besarnya return saham. Metode analisis data yang digunakan dalam penelitian ini adalah metode kuantitatif dengan pengujian asumsi klasik, serta analisis statistik yaitu analisis regresi linear berganda. Metode pengambilan sampel yang digunakan adalah purposive sampling.

Keywords: Earning Per Share, Debt To Equity Ratio, Price Earning Ratio, Return On Equity, and Stock Return

\section{PENDAHULUAN}

Penelitian ini bertujuan untuk mengetahui pengaruh rasio keuangan terhadap return saham pada perusahaan makanan dan minuman (food and beverages) yang terdaftar di Bursa Efek Indonesia tahun 2015-2017. Pemilihan perusahaan makanan dan minuman sebagai 
sampel penelitian didasari oleh suatu alasan bahwa produk makanan dan minuman merupakan salah satu komoditas eksport unggulan di sektor non-migas. Kebutuhan masyarakat akan produk makanan dan minuman akan selalu ada karena merupakan salah satu kebutuhan pokok. Didasarkan pada kenyataan tersebut diatas, perusahaan makanan dan minuman akan selalu survive. Penelitian ini akan menganalisis pengaruh kinerja perusahaan yang diukur dengan rasio keuangan terhadap tingkat return on equity perusahaan makanan dan minuman (food and beverages) yang terdaftar di Bursa Efek Indonesia pada tahun 20152017.

Terdapat berbagai jenis rasio keuangan yang dapat dianalisis oleh investor.Harahap (2007, dikutip oleh Jaenudin, 2012) menyimpulkan bahwa rasio keuangan merupakan angka yang diperoleh dari hasil perbandingan dari satu pos laporan keuangan dengan pos lainnya yang mempunyai hubungan yang relevan dan signifikan.Ang (1997, dikutip oleh Putri, 2012) mengelompokkan rasio keuangan ke dalam lima jenis rasio, yaitu rasio likuiditas, solvabilitas, profitabilitas, aktivitas, dan rasio pasar. Dalam penelitian ini, rasio keuangan yang akan dianalisa adalah rasio profitablitas. Rasio profitabilitas dapat digunakan untuk mengetahui tingkat profitabilitas suatu perusahaan.Rasio profitabilitas terdiri dari beberapa rasio, diantaranya adalah Earning Per Share, Debt To Equity Ratio, Price Earning Ratio, Return On Equity.

\section{Tujuan Penelitian}

Adapun tujuan dari penelitian ini, yaitu : "Untuk mengetahui pengaruh rasio keuangan terhadap return saham pada perusahaan makanan dan minuman yang terdaftar di BEI.

\section{TELAAH KEPUSTAKAAN}

\section{- Saham}

Pengertian Saham menurut (Nurmalasari,2012) saham dapat didefinisikan sebagai tanda penyertaan atau kepemilikan seseorang dalam suatu perusahaan atau perseroan terbatas. Menurut Handbook of Invstment in IndonesiaCapital Market yang dikeluarkan oleh Bapepam (Idawati dan Wahyudi, 2015) :

"Stock is defined as a certificate showing proof of ownership of a company, and shareholders have the right to claim on the income and asset of a company"

Menurut (Nurmalasari, 2012), wujud saham adalah selembar kertas yang menerangkan bahwa pemilik kertas tersebut adalah pemilik perusahaan yang menerbitkan surat berharga tersebut. Terdapat 2 jenis saham, yaitu :

$>$ Saham biasa

Menurut Jogiyanto (2000, dikutip oleh Anwar, 2012), pemegang saham biasa adalah pemilik dari perusahaan yang mewakili kepada manajemen untuk menjalankan operasi perusahaan.

$>$ Saham preferen.

Menurut Kieso et al (2011, dikutip oleh Idawati dan Wahyudi, 2015), saham preferen adalah "A special class of shares that possess certain preferences or features not possessed by ordinary shares"

\section{- Earning Per Share (EPS)}

Earning per share (EPS)

merupakan salah satu rasio yang dapat digunakan sebagai alat ukur profitabilitas suatu perusahaan. Menurut (Putri, 2012), earning per share (EPS) merupakan perbandingan antara laba bersih setelah pajak pada satu tahun buku dengan jumlah saham yang diterbitkan. (Putri, 2012) menyebutkan bahwa earning per share (EPS) adalah keuntungan perusahaan yang bisa dibagikan kepada pemegang saham.

- Rumus Earning Per Share (EPS)

Rasio earning per share (EPS) dapat dirumuskan sebagai berikut (Soedijono,1993): 


$$
\text { EPS }=\frac{\text { Laba bersih setelah pajak }}{\text { Jumlah saham beredar }}
$$

- Debt To Equity Ratio (DER)

Rasio Debt to Equity (DER) digunakan untuk mengukur seberapa baik struktur investasi suatu perusahaan. Rasio Debt To Equity Ratio (DER) dapat dirumuskan sebagai berikut menurut (Kasmir,2013):

$$
\text { DER }=\frac{\text { Total Hutang }}{\text { Ekuitas }}
$$

\section{- Price Earning Ratio (PER)}

Price Earning Ratio (PER) adalah salah satu rasio nilai pasar yang digunakan oleh analis fundamental dalam menganalisa keputusan investasinya. Rasio ini bergantung pada data pasar keuangan, seperti harga pasar saham biasa perusahaan. Analisis fundamental adalah analisis untuk menghitung nilai instrinsik perusahaan dengan menggunakan data keuangan perusahaan, nilai instrinsik perusahaan dapat diwujudkan dengan harga saham (Tandelilin, 2001).

Menurut (Sudana, 2011) "Price Earning Ratio(PER) adalah rasio yang mengukur tentang bagaimana investor menilai prospek pertumbuhan perusahaan di masa yang akan datang, dan tercermin pada harga saham yang bersedia dibayar oleh investor untuk setiap rupiah laba yang diperoleh perusahaan". Rasio Earning Ratio (PER) dapat dirumuskan sebagai berikut, menurut (Sudana, 2011):

$$
\mathbf{P E R}=\frac{\text { Laba Saham }}{\text { Laba per saham }}
$$

\section{- Return On Equity (ROE)}

Return on equity (ROE) merupakan rasio profitabilitas yang digunakan untuk mengetahui seberapa efektif perusahaan menghasilkan keuntungan dari modal yang dimilikinya. Menurut (Martin, 2014) :

"When net income is divided by the dollar amount of equity, we get the accounting return on the common stockholders' investment, or the return on equity"

Menurut (Martin, 2014), return on equity dapat dihitung menggunakan rumus sebagai berikut :

$$
\text { ROE }=\frac{\text { NetIncome }}{\text { CommonEquity }}
$$

\section{Hipotesis}

Dalam penelitian ini terdapat lima hipotesis yang diuji, yaitu :

- X1: Terdapat pengaruh signifikan antara Earning Per Share (EPR) dengan harga saham perusahaan makanan dan minuman yang terdaftar di BEI.

- X2: Terdapat pengaruh signifikan antara Debt To Equity Ratio (DER) terhadap harga saham perusahaan makanan dan minuman yang terdaftar di BEI.

- X3: Terdapat pengaruh signifikan antara Price Earning Ratio (PER) terhadap harga saham perusahaan makanan dan minuman yang terdaftar di BEI.

- X4: Terdapat pengaruh signifikan antara Earning Per Share (EPR) dengan harga saham perusahaan makanan dan minuman yang terdaftar di BEI.

- Y : Terdapat pengaruh signifikan antara Earning Per Share (X1), Debt To Equity Ratio (X2), Price Earning Ratio (X3), Return On Equity (X4) terhadap harga saham perusahaan makanan dan minuman yang terdaftar di BEI. 


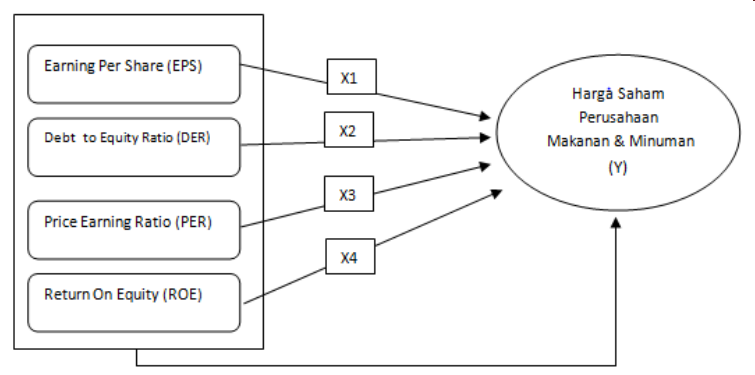

\section{METODE PENELITIAN}

Penelitian ini dilakukan terhadap sepuluh perusahaan makanan dan minuman yang terdaftar di BEI. Objek penelitian dalam penelitian ini adalah pengaruh Earning Per Share (X1), Debt To Equity Ratio (X2), Price Earning Ratio (X3), Return On Equity (X4) terhadap harga saham di perusahaan makanan dan minuman. Terdapat lima jenis variabel dalam penelitian ini, yaitu empat variabel independen dan satu variabel dependen.Variabel independen adalah variabel yang dapat mempengaruhi perubahan dalam variabel dependen dan mempunyai hubungan yang positif ataupun yang negatif bagi variabel dependen lainnya, sedangkan variabel dependen adalah variabel yang menjadi perhatian utama dalam suatu pengamatan (Kuncoro, 2013). Variabel independen dalam penelitian ini adalah pengaruh Earning Per Share (X1), Debt To Equity Ratio (X2), Price Earning Ratio (X3), Return On Equity (X4), sedangkan variabel dependen dalam penelitian ini adalah harga saham perusahaan makanan dan minuman (Y) yang terdaftar di BEI.

- Uji normalitas

Menurut Ghozali (2005, dikutip oleh Witjaksono,2010), uji normalitas bertujuan untuk menguji apakah dalam model regresi variabel pengganggu atau residual memiliki distribusi normal.

- Uji multikolinearitas

Uji multikolinearitas dilakukan untuk mengetahui apakah terdapat hubungan antara satu variabel bebas dengan variabel bebas lainnya. Menurut Witjaksono (2010).

- Uji Heteroskedastisitas

Menurut Witjaksono (2010), uji heteroskedastisitas bertujuan untuk menguji apakah dalam model regresi terjadi ketidaksamaan variance dari residual suatu pengamatan yang lain. Suato model regresi yang baik adalah model regresi yang tidak mengandung heteroskedastisitas.

\section{HASIL PENELITIAN}

\section{HasilPengujianMultikolinearitas:}

Sumber: Diolah penulis dengan aplikasi Eviews 8.0

Pada tabel 4.2. menunjukkan bahwa variabel DER, EPS, PER dan ROA memiliki nilai lebih besar dari 0,8. Artinya, terdapat hubungan multikolinearitas pada data Earning Per Share (EPS), Debt To Equity Ratio (DER), Price Earning Ratio (PER), Return On Equity (ROE).

Hal ini menunjukkan bahwa dengan adanya multikolinearitas, nilai standar error menjadi besar, sehingga tidak dapat mengukur variabel terikat secara presisi.

\section{Uji Autokorelasi}

Uji autokorelasi adalah sebuah analisis statistik yang dilakukan untuk mengetahui apakah ada korelasi variabel yang ada di dalam model prediksi dengan perubahan waktu. Dalam penelitian ini, uji autokorelasi dilakukan dengan uji Durbin-Watson. 
Dapat disimpulkan bahwa besarnya nilai statistik Durbin-Watson adalah 0,428458. Dengan jumlah variabel (k) sebesar empat dan jumlah observasi (n) sebanyak 30. Berdasarkan data yang ditunjukkan pada tabel 4.3.2.2 di atas, didapatkan nilai dU sebesar 1,7386 dan nilai 4dU sebesar 3,571542. Hal ini menjadikan dU > DW < 4-dU sehingga dapat ditarik kesimpulan bahwa terdapat autokorelasi (Autokorelasi adalah terjadi korelasi antara observasi ke-i dengan observasi ke-i-1) sehingga sampel ke-10, nilainya dipengaruhi oleh sampel ke-9. Sampel ke-9, nilainya dipengaruhi oleh sampel ke-8, dst.

Hasil probabilitas variabel DER, PER dan $\mathrm{C}>0.05$. Hal ini menunjukkan bahwa dengan tingkat keyakinan 95\% tidak terdapat hasil heteroskedastisitas. Untuk probabilitas variabel EPS, ROE $<0.05$ menunjukkan bahwa terdapat hasil heteroskedastisitas.

Hasil probabilitas jarque-bera sebesar $0.164523>0.05$. Maka dapat ditarik kesimpulan bahwa dengan tingkat keyakinan $95 \%$ residual data terdistribusi secara normal.

Persamaan regresi linear berganda sebagai berikut:

LSAHAM $=-6966.632+4327.042 *$ LDER $-24.14125^{*}$ LEPS $+6.09 *$ PER + 21883.07*LROE

Arti dari persamaan regresi berganda tersebut adalah sebagai berikut:

- Jika Earning Per Share (EPS), Debt To Equity Ratio (DER), Price Earning Ratio (PER), Return On Equity (ROE) bernilai sangat kecil (nol), maka harga saham makanan dan minuman akan turun dengan nilai -6966.632 poin.

- Jika Debt To Equity Ratio (DER), naik 1 point, dan Earning Per Share (EPS), Price Earning Ratio (PER) dan Return On Equity (ROE) dianggap konstan, maka harga saham makanan dan minuman akan naik senilai 4327.042poin.

- Jika dan Earning Per Share (EPS) naik 1 poin, dan Debt To Equity Ratio (DER), Price Earning Ratio (PER) dan Return On Equity (ROE) dianggap konstan, maka harga saham makanan dan minuman akan turun senilai 24.14125 poin.

- Jika Price Earning Ratio (PER) naik 1 poin, dan Earning Per Share (EPS), Debt To Equity Ratio (DER) dan Return On Equity (ROE) dianggap konstan, maka harga saham makanan dan minuman akan naik 6.09 poin.

- Jika Return On Equity (ROE) naik 1 poin, dan Earning Per Share (EPS), Debt To Equity Ratio (DER) dan Price Earning Ratio (PER) dianggap konstan, maka harga saham makanan dan minuman akan naik 21883.07 poin.

\section{Pengujian Hipotesis}

\section{Uji Parsial}

Pengujian hipotesis satu, dua, dan tiga dilakukan dengan uji-t parsial. Berikut hasil pengujiannya:

- Hipotesis 1

Ho $_{1}: \beta_{1}=0$ (tidak terdapat pengaruh yang signifikan antara Debt To Equity Ratio (DER) terhadap harga saham makanan dan minuman secara parsial)

$\mathrm{Ha}_{1}: \beta_{1} \neq 0$ (terdapat pengaruh yang signifikan antara Debt To Equity Ratio (DER) terhadap harga saham makanan dan minuman secara parsial)

Probabilitas DER terhadap saham adalah 0.1507. Karena probabilitas Debt To Equity Ratio (DER) lebih besar daripada nilai signifikansi $(\alpha)$ sebesar 5\%, maka hipotesis 1 diterima. Artinya, tidak terdapat pengaruh signifikan antara Debt To Equity Ratio (DER) terhadap harga saham makanan dan minuman secara parsial. 
- Hipotesis 2

Ho2 : $\beta 2=0$ (tidak terdapat pengaruh yang signifikan antara Earning Per Share (EPS) terhadap harga saham makanan dan minuman secara parsial)

Ha2: $\beta 2 \neq 0$ (terdapat pengaruh yang signifikan antara Earning Per Share (EPS) terhadap harga saham makanan dan minuman secara parsial)

Probabilitas Earning Per Share (EPS) terhadap saham adalah 0.0017. Karena probabilitas Earning Per Share (EPS) lebih kecil daripada nilai signifikansi signifikansi $(\alpha)$ sebesar 5\%, maka hipotesis 2 ditolak. Artinya, terdapat pengaruh signifikan antara Earning Per Share (EPS) terhadap harga saham makanan dan minuman secara parsial.

- Hipotesis 3

Ho3 : $\beta 3=0$ (tidak terdapat pengaruh yang signifikan antara nilai Price Earning Ratio $(P E R)$ terhadap harga saham makanan dan minuman secara parsial)

Ha3 : $\beta 3 \neq 0$ (terdapat pengaruh yang signifikan antara Price Earning Ratio (PER) terhadap harga saham makanan dan minuman secara parsial.

Probabilitas Price Earning Ratio (PER) terhadap saham adalah 0.0679. Karena probabilitas Price Earning Ratio (PER) lebih besar daripada nilai signifikansi signifikansi $(\alpha)$ sebesar 5\%, maka hipotesis 3 diterima. Tidak terdapat pengaruh signifikan antara Price Earning Ratio (PER) terhadap harga saham makanan dan minuman secara parsial.

- Hipotesis 3

Ho3 : $\beta 3=0$ (tidak terdapat pengaruh yang signifikan antara nilai Return On Equity (ROE) terhadap harga saham makanan dan minuman secara parsial)

Ha3 : $\beta 3 \neq 0$ (terdapat pengaruh yang signifikan antara Return On Equity (ROE) terhadap harga saham makanan dan minuman secara parsial.

Probabilitas Return On Equity (ROE) terhadap saham adalah 0.0000. Karena probabilitas Return On Equity (ROE) lebih kecil daripada nilai signifikansi $(\alpha)$ sebesar 5\%, maka hipotesis 3 ditolak. Artinya, terdapat pengaruh signifikan antara Return On Equity (ROE) terhadap harga saham makanan dan minuman secara parsial.

Hasil pengujian secara parsial untuk periode 2015 sampai dengan 2016 dapat dilihat pada tabel 4.7. di atas. Hasil uji-t dapat disimpulkan bahwa Earning Per Share (EPS) dan Return On Equity (ROE) memiliki pengaruh signifikan terhadap harga saham perusahaan makanan dan minuman pada periode 2015-2017 dengan tingkat keyakinan 95\%, sedangkan, Debt To Equity Ratio (DER) dan Price Earning Ratio (PER) memiliki pengaruh tidak signifikan secara parsial terhadap harga saham perusahaan makanan dan minuman pada periode 2015-2017.

\section{Uji F (Simultan)}

Pada pengujian ini, dilakukan uji $\mathrm{F}$ untuk mengetahui apakah terdapat pengaruh signifikan dari semua variabel independen secara bersamaan terhadap variabel dependen. Dari tabel di atas, didapat nilai signifikansi uji $\mathrm{F}$ sebesar $0.0000<0.05$. Hal ini berarti bahwa Earning Per Share (EPS), Return On Equity (ROE), Debt To Equity Ratio (DER) dan Price Earning Ratio $(P E R)$ secara bersama-sama signifikan mempengaruhi harga saham properti pada periode 2015-2017 dengan tingkat keyakinan 95\%.

Koefisien Determinasi $\left(\mathbf{R}^{2}\right)$

Uji koefisien determinasi $\left(\mathrm{R}^{2}\right)$ digunakan untuk mengukur seberapa besar pengaruh (kontribusi) yang diberikan variabel independen terhadap variabel dependen. Dari tabel 4.7. di atas, didapat nilai koefisien determinasi (adjusted $R$-squared) dalam penelitian ini sebesar 0.740861. Hal ini berarti bahwa variabel-variabel independen Earning Per Share (EPS), Return On Equity (ROE), Debt To Equity Ratio (DER) dan Price Earning Ratio (PER) 
mempengaruhi variabel harga saham makanan dan minuman sebesar 74,09\%, dimana sisanya sebesar $25,91 \%$ dipengaruhi oleh variabel diluar penelitian ini.

\section{Pembahasan}

Pada penelitian mengenai pengaruh Earning Per Share (EPS), Return On Equity (ROE), Debt To Equity Ratio (DER) dan Price Earning Ratio (PER) terhadap harga saham makanan dan minuman pada periode 2015-2017 ini didapatkan hasil sebagai berikut:

- H1 : Pengaruh Debt To Equity Ratio (DER) secara parsial terhadap harga saham makanan dan minuman.

Secara parsial, Debt To Equity Ratio (DER) memiliki pengaruh positif pada harga saham makanan dan minuman periode 2015-2017. Hubungan Debt To Equity Ratio (DER) yang positif sehingga tidak mempengaruhi harga saham secara signifikan dikarenakan investor menyadari adanya kelemahan dalam rasio Debt To Equity Ratio (DER) sehingga ada investor yang tidak memperhitungkan rasio Debt To Equity Ratio (DER) dalam menentukan harga saham.

- H2 : Pengaruh Earning Per Share (EPS) secara parsial terhadap harga saham makanan dan minuman.

Secara parsial, Earning Per Share (EPS) memiliki hubungan negatif signifikan berpengaruh terhadap harga saham makanan dan minuman periode 2015-2017.

Dimana turunnya rasio Earning Per Share (EPS) dapat meningkatkan harga saham karena kekuatan perusahaan dalam melakukan ekspansi sehingga dapat meyakinkan inventor untuk terus berinvestasi.

- H3 : Pengaruh Price Earning Ratio (PER) secara parsial terhadap harga saham makanan dan minuman.

Secara parsial, Price Earning Ratio (PER) memiliki hubungan positif tidak signifikan terhadap harga saham makanan dan minuman periode 2015-2017. Dimana bagi investor Price Earning Ratio (PER) tinggi kurang baik untuk investasi jangka panjang karena saham itu mempunyai volatilitas yang tinggi sehingga memiliki potensi risiko yang tinggi pula.

- H4 : Pengaruh Return On Equity (ROE) secara parsial terhadap harga saham makanan dan minuman.

Secara parsial, Return On Equity (ROE)memiliki hubungan negatif yang signifikan berpengaruh terhadap harga saham makanan dan minuman periode 2015-2017.

Dimana turunnya rasio Return On Equity (ROE) dapat meningkatkan harga saham karena semakin tinggi rasio Return On Equity (ROE) maka semakin tinggi pula nilai perusahaan sehingga menjadi daya tarik bagi para investor untuk menanamkan modal perusahaannya.

- H4 : Earning Per Share (EPS), Return On Equity (ROE), Debt To Equity Ratio (DER) dan Price Earning Ratio (PER) terhadap harga saham properti.

Variabel Earning Per Share (EPS), Return On Equity (ROE), Debt To Equity Ratio (DER) dan Price Earning Ratio (PER) secara bersama-sama memiliki pengaruh signifikan terhadap harga saham makanan dan minuman periode 2015-2017. Secara bersama-sama Earning Per Share (EPS), Return On Equity (ROE), Debt To Equity Ratio (DER) dan Price Earning Ratio (PER) memiliki pengaruh signifikan terhadap harga saham emiten LQ45 yang terdaftar di Bursa Efek Indonesia.

\section{KESIMPULAN}

Berdasarkan pengolahan data diatas dapat disimpulkan bahwa secara parsial, Earning Per Share (EPS) \& Return On Equity (ROE) memiliki pengaruh negatif signifikan terhadap harga saham makanan dan minuman, sedangkan Debt To Equity Ratio (DER) dan Price Earning Ratio (PER) memiliki pengaruh positif sehingga tidak signifikan terhadap harga saham makanan dan minuman. Secara bersama-sama, variabel Earning Per Share (EPS), Return On Equity (ROE), Debt To Equity Ratio 
(DER) dan Price Earning Ratio (PER) memiliki pengaruh signifikan terhadap harga saham makanan dan minuman. Variabel independen tersebut mempengaruhi variabel harga saham makanan dan minuman sebesar $74,09 \%$, dimana sisanya sebesar $25,9 \%$ dipengaruhi oleh variabel diluar penelitian ini.

\section{Kesimpulan dan Saran \\ Kesimpulan}

Berdasarkan hasil analisis dan pengujian hipotesis yang dilakukan, maka dapat disimpulkan bahwa:

- Debt To Equity Ratio (DER) \& Price Earning Ratio (PER) secara parsial mempunyai pengaruh positif yang artinya rasio Debt To Equity Ratio (DER) \& Price Earning Ratio (PER) tidak memiliki pengaruh signifikan terhadap harga saham perusahaan makanan dan minuman periode 2015 sampai dengan 2017 dengan tingkat keyakinan $95 \%$.

- Net Profit Margin (Earning Per Share (EPS) \& Return On Equity (ROE) secara parsial mempunyai pengaruh negatif yang artinya rasio Net Profit Margin (Earning Per Share (EPS) \& Return On Equity (ROE) memiliki pengaruh signifikan terhadap harga saham perusahaan makanan dan minuman periode 2015 sampai dengan 2017 dengan tingkat keyakinan $95 \%$.

- Earning Per Share (EPS), Return On Equity (ROE), Debt To Equity Ratio (DER) dan Price Earning Ratio (PER) secara bersama-sama mempunyai pengaruh terhadap harga saham perusahaan makanan dan minuman periode 2015 sampai dengan 2017 dengan tingkat keyakinan $95 \%$.

\section{Saran}

Berdasarkan hasil penelitian dan kesimpulan ini, maka saran yang dapat diberikan adalah sebagai berikut:

- Bagi investor

Bagi para investor yang akan memutuskan berinvestasi saham sangat penting memperhatikan faktor internal perusahaan dan faktor eksternal perusahaan.

Dimana dalam memperhatikan faktor internal perusahaan investor perlu dengan detail memperhatikan rasio - rasio keuangan perusahaan sehingga dapat mengetahui kondisi stabilitas keuangan perusahaan dan dapat mengambil keputusan atau memprediksi harga saham perusahaan. Beberapa hal yang sangat penting di perhatikan oleh investor untuk faktor internal adalah mengetahui seberapa besar net profit margin perusahaan dan dikaitkan dengan karakteristik sektor perusahaan tersebut, seperti sektor perusahaan makanan dan minuman yang berbeda dengan sektor industri lainnya.

- Bagi Perusahaan

Untuk perusahaan perlu memperhatikan laporan keuangan perusahaannya sehingga para calon investor maupun investor dapat mengetahui detail kondisi keuangan perusahaan sehingga dengan demikian dapat menarik investor untuk melakukan investasi di perusahaan tersebut. Laporan keuangan sangatlah penting bagi perusahaan untuk membangun kepercayaan investor terhadap perusahaan dimana para investor dapat melihat bagaimana kondisi perusahaan tersebut, sehingga rasio-rasio keuangan seperti net profit margin dapat mempengaruhi minat investor dalam melakukan investasi ke suatu perusahaan.

- Bagi akademik

Dalam penelitian ini menggunakan empat variabel independen dalam periode 2015-2017. Pada penelitian ini memiliki keterbatasan pada laporan keuangan yang hanya terbatas maksimal 3 tahun dengan sampel sebanyak 10 perusahaan sehingga belum nampak pengaruh rasio-rasio keuangan terhadap harga saham pada satu sektor perusahaan. Penelitian yang sama di masa mendatang diharapkan dapat menggunakan periode yang 
lebih lama sehingga diharapkan dapat terlihat pengaruh dari rasio-rasio keuangan terhadap satu sektor perusahaan.

\section{DAFTAR PUSTAKA}

Abdul Halim. (2005). Analisis Investasi. Jakarta: Salemba Empat.

Abied Luthfi Safitri. (2013). Pengaruh Earning Per Share, Price Earning Ratio, Return On Asset, Debt to Equity Ratio dan Market Value Added Terhadap Harga Saham dalam Kelompok Jakarta Islamic Index. Management Analysis Journal

Agus, R. Sartono. (2008). Manajemen Keuangan Teori dan Aplikasi. Edisi Keeempat. Yogyakarta: BPFE..

Aldiansyah, Cahya Putra, Saryadi dan Wahyu Hidayat. (2013).

Pengaruh Kinerja Keuangan Terhadap Harga Saham Pada Perusahaan Bumn (Non-Bank) Yang Terdaftar Di Bursa Efek Indonesia. Journal Of Social And Politic Tahun 2013.

Ang, Robert. (2007). Buku Pintar Pasar Modal Indonesia (The Inteligent Guide To Indonesia Capital Market).Edisi Pertama. Jakarta: Mediasoft Indonesia.

Angrawit, Kusumawardani. (2011).

Analisis Pengaruh EPS, PER, ROE, FL, DER, CR, ROA Pada Harga Saham dan Dampaknya terhadap Kinerja Perusahaan LQ45 yang Terdaftar di BEI Periode 2005-2009. Jurnal Ekonomi.

Brigham, Eugena F., dan Joel F. Houston. (2013).

Dasar-dasar Manajemen Keuangan. Jakarta: Salemba Empat

Aulianisa, Fitri. (2012). PengaruhFaktor Fundamental Dan RisikosistematikTerhadapHargaSaham Di PasarmodalSyariah (StudiEmpiris JII Di BEI Tahun 2007-2010). Retrieved October 11, 2018, from www.googlescholar.com.

Anastasia, Njo; Gunawan, Yanny Widiastuty \& Wijiyanti, Imelda. (2005). Analisis Faktor Fundamental Dan Risiko Sistematik Harga Saham Properti Di BEJ. Retrieved November 18, 2018, from www.googlescholar.com.

Anisma, Yuneita. (2012). Faktor-Faktor Yang MempengaruhiHargaSaham Perusahaan Perbankan Yang Listing Di Bursa Efek Indonesia (BEI). Retrieved October 11, 2018, from www.googlescholar.com.

Anwar, Solichin. (2012). PengaruhFaktor Fundamental Dan RisikoSistematikTerhadapHargaSaham Perusahaan SektorPembiayaan Di BEI Tahun 20072008. Retrieved October 30, 2017, from www.googlescholar.com.

Darmawansyach, Budi. (2012). AnalisisPengaruhFaktor-Faktor Fundamental TerhadapHargaPasarSaham Perusahaan Agrobisnis Di Bursa Efek Indonesia. Retrieved October 30, 2018 from www.googlescholar.com.

Darnita, Elis. (2014). Analisis Pengaruh Return On Assets (ROA), Return On Equity (ROE), Net Profit Margin (NPM) Dan Earning Per Share (EPS) Terhadap Harga Saham (Studi 
